\title{
Selection of Prefabricated Components Supplier for Prefabricated Building Based on BP Neural Network Model
}

\author{
Hongchun WANG and Xunfan GUO ${ }^{1}$ \\ School of Urban Economics and Management, Beijing University of Civil \\ Engineering and Architecture, China
}

\begin{abstract}
The application of prefabricated components (PCs) is accelerating the transformation of the traditional building model to the prefabricated building supply chain, and it also places higher requirements on suppliers. How to efficiently select high-quality suppliers has become an urgent problem for engineering general contractors. This paper fully considers the characteristics of prefabricated building and the elements of supplier selection, combining the Supply Chain Operations Reference (SCOR) model to analyze the process of prefabricated building. Based on the characteristics of prefabricated building and PCs, we establish a supplier selection evaluation index system for PCs of prefabricated building. Next, we construct a supplier selection evaluation model through Analytic Hierarchy Process (AHP) and Back Propagation (BP) neural network, and verify the feasibility of the model through sample data simulation sex. Hope to provide a scientific decision-making method for the selection of prefabricated building PCs suppliers.
\end{abstract}

Keywords. Prefabricated components, Prefabricated components suppliers, BP neural network.

\section{Introduction}

The prefabricated building is a new building form. The PCs prefabricated in the factory are transported and distributed to the construction site, and a stable and orderly installation and connection process is carried out to construct a new building. Due to the late start of prefabricated construction in China, there are still major problems in the accuracy, quality, hole reservation, and transportation of PCs. Products and services vary from vendor to supplier. Therefore, the selection of PC component suppliers has become a problem that needs to be solved urgently.

As early as 1,966 American scholars Dickson[1], through surveyed and analyzed 23 vendor selection evaluation indicators. He believed that quality is the first element of consideration for supplier selection. Weber[2] analyzed the three important indicators of price, on-time delivery and quality based on the literature, and used DEA for supplier selection and evaluation.

At present, the research on the suppliers of prefabricated building PC components is still relatively limited. Zhang[3] established a PCs supplier selection index system from the PCs production process and characteristics, and selected suppliers based on the evaluation index system through the GRAP-VIKOR model. Shi et al.[4] obtained the

${ }^{1}$ Corresponding Author, Xunfan GUO, School of Urban Economics and Management, Beijing University of Civil Engineering and Architecture, China; E-mail: 954059485@qq.com. 
evaluation index system of PCs suppliers for prefabricated buildings from the integrated analysis of the SCOR model, benchmarking enterprises, and the government. Yang et al.[5] constructed a prefabricated building PCs supplier selection evaluation index system from the three dimensions of PCs product advantages, supplier operation management, and supplier cooperation potential. They used the entropy method to weight the index system, the TODIM method to calculate the dominance, and the ranking selection was based on the comprehensive score of the evaluation object. From the perspective of the construction unit, Zhang[6] established an evaluation index system for the selection of PCs suppliers for prefabricated buildings based on the design characteristics, manufacturing characteristics, loading and unloading and transportation of the components, and established a supplier evaluation method by introducing the VIKOR multi-attribute decision-making method.

The research on the selection of PCs suppliers for prefabricated buildings is mainly divided into two aspects: the establishment of an evaluation index system and an evaluation model. There are many evaluation methods for suppliers to select evaluation index system, such as VIKOR method, hierarchical analysis method, GRAP-VIKOR method, TOPSIS method, etc. Supplier selection is a complex process that involves many uncertainties. Compared with the traditional method, the BP neural network model has a stronger ability to deal with complex nonlinear relationships, and can perform error analysis through numerical simulation to evaluate the effectiveness of the model. At the same time, BP has a stronger ability to adapt to changes in the external environment[7]. Therefore, this paper applies the BP neural network model to solve the supplier selection problem.

\section{Prefabricated Building PCs Supplier Selection Indicator System}

SCOR is a commonly used supply chain reference model and diagnostic tool that breaks down the supply chain into three layers of standards[4]. Starting from these three levels, companies can classify and refine the elements contained in each level, fully improve the company's own business processes, and discover the deficiencies of each process element to improve its weaknesses and strengthen the company's competitive advantage. In order to further summarize the characteristics of suppliers, with the help of SCOR's processes and practices to find key supplier evaluation indicators. The configuration layer is finally divided into five layers: planning, procurement, production, transportation and service, which provides basis and reference for the construction of the indicator system.

The literatures are the main source basis for evaluating the selection of index system in this paper. In order to ensure the quality of the selected indicators, this article mainly selects two parts of related documents as the data source. That is, the prefabricated building suppliers and the selection of suppliers.

The setting of the indicator system not only takes into account the current needs, but also incorporates the factor of long-term cooperative development. Establish an index system for the selection of prefabricated building PCs suppliers from two aspects: technical capability and comprehensive enterprise strength. Finally, an evaluation index system including 5 first-level indicators and 19 second-level indicators has been formed, as shown in table 1. We determine the index weight through AHP. By combining expert opinions and applying the 1-9 scale method to compare each factor, we construct a judgment matrix and analyze the consistency, calculate the weight of each index and merge the results into the table 1 . 
Table1. Evaluation Index System for Supplier Selection of Prefabricated Building PCs

\begin{tabular}{|c|c|c|c|c|c|}
\hline $\begin{array}{l}\text { The } \\
\text { target } \\
\text { layer }\end{array}$ & $\begin{array}{c}\text { The criteria } \\
\text { layer }\end{array}$ & $\begin{array}{c}\text { The metrics } \\
\text { layer }\end{array}$ & $\begin{array}{l}\text { Description of } \\
\text { the indicator }\end{array}$ & Type & $\begin{array}{l}\text { Metric } \\
\text { weights }\end{array}$ \\
\hline \multirow{10}{*}{ A1 } & \multirow{4}{*}{$\begin{array}{c}\text { Quality } \\
\text { indicators B1 }\end{array}$} & PCs quality C1 & $\begin{array}{l}\text { The quality and } \\
\text { reliability of PCs }\end{array}$ & $\begin{array}{l}\text { Benefit- } \\
\text { oriented }\end{array}$ & 0.1751 \\
\hline & & $\begin{array}{l}\text { Deepen design } \\
\text { level C2 }\end{array}$ & $\begin{array}{l}\text { The secondary } \\
\text { deepening } \\
\text { design of PCs }\end{array}$ & $\begin{array}{l}\text { Benefit- } \\
\text { oriented }\end{array}$ & 0.0854 \\
\hline & & $\begin{array}{l}\text { Qualified rate } \\
\text { of PCs C3 }\end{array}$ & $\begin{array}{l}\text { Number of } \\
\text { qualified } \\
\text { products/total } \\
\text { number of } \\
\text { products }\end{array}$ & $\begin{array}{l}\text { Benefit- } \\
\text { oriented }\end{array}$ & 0.1014 \\
\hline & & $\begin{array}{c}\text { Quality } \\
\text { assurance } \\
\text { system C4 }\end{array}$ & $\begin{array}{l}\text { Systems and } \\
\text { methods }\end{array}$ & $\begin{array}{l}\text { Benefit- } \\
\text { oriented }\end{array}$ & 0.0308 \\
\hline & \multirow{4}{*}{$\begin{array}{c}\text { Product } \\
\text { competitiveness } \\
\text { B2 }\end{array}$} & PCs price C5 & $\begin{array}{l}\text { Lower prices } \\
\text { at the same } \\
\text { quality level }\end{array}$ & $\begin{array}{l}\text { Cost- } \\
\text { based }\end{array}$ & 0.1063 \\
\hline & & $\begin{array}{c}\text { PCs } \\
\text { standardization } \\
\text { level C6 } \\
\end{array}$ & $\begin{array}{l}\text { Unify through } \\
\text { standards }\end{array}$ & $\begin{array}{l}\text { Benefit- } \\
\text { oriented }\end{array}$ & 0.0670 \\
\hline & & $\begin{array}{l}\text { Production of } \\
\text { flexible C7 }\end{array}$ & $\begin{array}{c}\text { Diversified } \\
\text { production to } \\
\text { meet the } \\
\text { individual needs } \\
\text { of customers }\end{array}$ & $\begin{array}{l}\text { Benefit- } \\
\text { oriented }\end{array}$ & 0.0257 \\
\hline & & $\begin{array}{l}\text { Production } \\
\text { equipment } \\
\text { advanced C8 }\end{array}$ & $\begin{array}{l}\text { Better hardware } \\
\text { equipment to } \\
\text { ensure } \\
\text { high-quality, } \\
\text { high-efficiency } \\
\text { requirements }\end{array}$ & $\begin{array}{l}\text { Benefit- } \\
\text { oriented }\end{array}$ & 0.0150 \\
\hline & \multirow[b]{2}{*}{$\begin{array}{c}\text { Transport and } \\
\text { distribution B3 }\end{array}$} & $\begin{array}{c}\text { Rate of } \\
\text { on-time } \\
\text { delivery C9 }\end{array}$ & $\begin{array}{c}\text { Number of } \\
\text { on-time } \\
\text { deliveries / } \\
\text { number of total } \\
\text { deliveries }\end{array}$ & $\begin{array}{l}\text { Benefit- } \\
\text { oriented }\end{array}$ & 0.1280 \\
\hline & & $\begin{array}{c}\text { Ministry } \\
\text { transport } \\
\text { protection } \mathrm{C} 10\end{array}$ & $\begin{array}{l}\text { The protection } \\
\text { of parts from the } \\
\text { factory to the } \\
\text { loading and } \\
\text { unloading and } \\
\text { transportation } \\
\text { process at the } \\
\text { construction site }\end{array}$ & $\begin{array}{l}\text { Cost- } \\
\text { based }\end{array}$ & 0.0404 \\
\hline
\end{tabular}




\begin{tabular}{|c|c|c|c|c|}
\hline & $\begin{array}{c}\text { Geographical } \\
\text { advantage C11 }\end{array}$ & $\begin{array}{c}\text { The distance } \\
\text { and traffic } \\
\text { advantages } \\
\text { between the PCs } \\
\text { factory and the } \\
\text { construction site }\end{array}$ & $\begin{array}{l}\text { Cost- } \\
\text { based }\end{array}$ & 0.0170 \\
\hline \multirow{3}{*}{$\begin{array}{l}\text { Enterprise } \\
\text { cooperation } \\
\text { potential B4 }\end{array}$} & $\begin{array}{l}\text { Contract } \\
\text { performance } \\
\text { rate } \mathrm{C} 12\end{array}$ & $\begin{array}{l}\text { Implementation } \\
\text { and completion } \\
\text { of contractual } \\
\text { requirements and } \\
\text { agreements }\end{array}$ & $\begin{array}{l}\text { Benefit- } \\
\text { oriented }\end{array}$ & 0.0667 \\
\hline & $\begin{array}{c}\text { Goal } \\
\text { consistency } \\
\text { C13 } \\
\end{array}$ & $\begin{array}{l}\text { Whether the two } \\
\text { partners can } \\
\text { agree on the goal }\end{array}$ & $\begin{array}{l}\text { Benefit- } \\
\text { oriented }\end{array}$ & 0.0254 \\
\hline & $\begin{array}{c}\text { Similar } \\
\text { corporate } \\
\text { culture C14 }\end{array}$ & $\begin{array}{l}\text { Whether the two } \\
\text { sides of the } \\
\text { enterprise have } \\
\text { similar business } \\
\text { philosophy }\end{array}$ & $\begin{array}{l}\text { Benefit- } \\
\text { oriented }\end{array}$ & 0.0146 \\
\hline \multirow{5}{*}{$\begin{array}{c}\text { Enterprise } \\
\text { development } \\
\text { potential B5 }\end{array}$} & $\begin{array}{l}\text { Information } \\
\text { technology } \\
\text { C15 }\end{array}$ & $\begin{array}{l}\text { Information } \\
\text { technology or } \\
\text { information } \\
\text { sharing } \\
\text { platforms such } \\
\text { as BIM, RFID, } \\
\text { etc. }\end{array}$ & $\begin{array}{l}\text { Benefit- } \\
\text { oriented }\end{array}$ & 0.0346 \\
\hline & $\begin{array}{l}\text { Corporate debt } \\
\text { capacity C16 }\end{array}$ & $\begin{array}{c}\text { The ability to } \\
\text { repay debt }\end{array}$ & $\begin{array}{c}\text { Benefit } \\
\text { type }\end{array}$ & 0.0110 \\
\hline & $\begin{array}{c}\text { Corporate } \\
\text { finance } \\
\text { capacity C17 }\end{array}$ & $\begin{array}{l}\text { The size of the } \\
\text { money that } \\
\text { companies may } \\
\text { be able to } \\
\text { finance }\end{array}$ & $\begin{array}{l}\text { Benefit- } \\
\text { oriented }\end{array}$ & 0.0126 \\
\hline & $\begin{array}{c}\text { Corporate } \\
\text { profitability } \\
\text { C18 }\end{array}$ & $\begin{array}{l}\text { The ability of } \\
\text { an enterprise } \\
\text { to make a profit }\end{array}$ & $\begin{array}{l}\text { Benefit- } \\
\text { oriented }\end{array}$ & 0.0107 \\
\hline & $\begin{array}{l}\text { Research cost } \\
\text { rate } C 19\end{array}$ & $\begin{array}{l}\text { The ratio of } \\
\text { research and } \\
\text { development } \\
\text { expenditure to } \\
\text { total expenditure }\end{array}$ & $\begin{array}{l}\text { Cost- } \\
\text { based }\end{array}$ & 0.0065 \\
\hline
\end{tabular}




\section{Selection Model Based on BP Neural Network}

\subsection{BP Neural Network}

BP neural network is a multi-layer feedforward neural network, the process mainly includes two stages. The first stage is the forward propagation of the signal, from the input layer to the output layer through the hidden layer, and the second stage is the back propagation of errors, from the output layer to the input layer through the hidden layer. The BP neural network can master the mapping relationship between input and output through machine learning, and incorporate human factors into the simulation function during the data training process to achieve the effect of artificial simulation.

\subsection{Selection of Study Subject}

This paper applies the BP neural network model to the selection of prefabricated buildings suppliers from a management perspective, so the expert scoring method is used to fit a series of data for analysis and calculation. With the continuous development of prefabricated building informatization construction and the blessing of sufficient technology, the required data will be directly obtained from the database system. This paper selects the indicator data of 25 candidate suppliers as the sample for analysis, and uses a 10-point system to score the indicator data of the sample.

\subsection{The Establishment and Training of BP Neural Network}

The establishment of a BP neural network model usually considers the number of neurons in the input layer, the number of neurons in the output layer, the number of hidden layers, the number of neurons in the hidden layer, the training function, and the allowable error range. A large number of fitting trainings reflects that a BP neural network with a single hidden layer can realize simple data fitting analysis by changing the number of neurons in the hidden layer. Therefore, this article chooses to build the neural network model with only one hidden layer, that is, the architecture of "input layer1 hidden layer-output layer".

The 19 indicators data of the suppliers in the sample is used as the input layer, and the comprehensive index of the supplier is used as the output value. In determining the number of neurons in the hidden layer, if too few neurons are used, the results will be under-fitting. On the contrary, using too many neurons can also cause some problems. First, too many neurons in the hidden layer may lead to overfitting. Even if the amount of information contained in the training data is sufficient, too many neurons in the hidden layer will increase the training time, making it difficult to achieve the desired effect. Obviously, choosing an appropriate number of hidden layer neurons is crucial. The commonly used empirical formulas are as follows:

$$
\begin{gathered}
N_{h}=\frac{N_{S}}{\alpha \times\left(N_{i}+N_{h}\right)} \\
N_{h}=\sqrt{N_{i}+N_{o}} \\
N_{h}=\sqrt{N_{i} \times N_{p}}
\end{gathered}
$$

Where: $N_{h}$ represents hidden layer neurons; $N_{i}$ represents the number of input layer neurons; $N_{o}$ represents the number of output layer neurons; $N_{s}$ represents the number 
of training set samples; $\alpha$ is a free variable, usually in the range of 2-10.

We use the MATLAB neural network toolbox to simulate the process. The toolbox has a random initial weight, and the machine will automatically correct the initial weight during the training process to reduce the error between the predicted value and the actual value.

The first 20 groups are used as training samples for neural network training and the last 5 groups are test samples for neural networks. During network training, the number of neurons in the parameters and hidden layers is constantly modified to improve the accuracy of neural network fitting. When the error between the actual value and the predicted value is less than the pre-set allowable error, the neural network can be considered qualified and the training process is over. Otherwise, retrain the neural network until the requirements are met. After repeated testing, a function of relative optimal fit is obtained when the number of hidden layer neurons is 10 . The model of 10hidden layer neurons is then trained several times to get the model with the highest fit, and the final $\mathrm{R}$ is 0.97398 , and the fit result is shown in figure 1 .
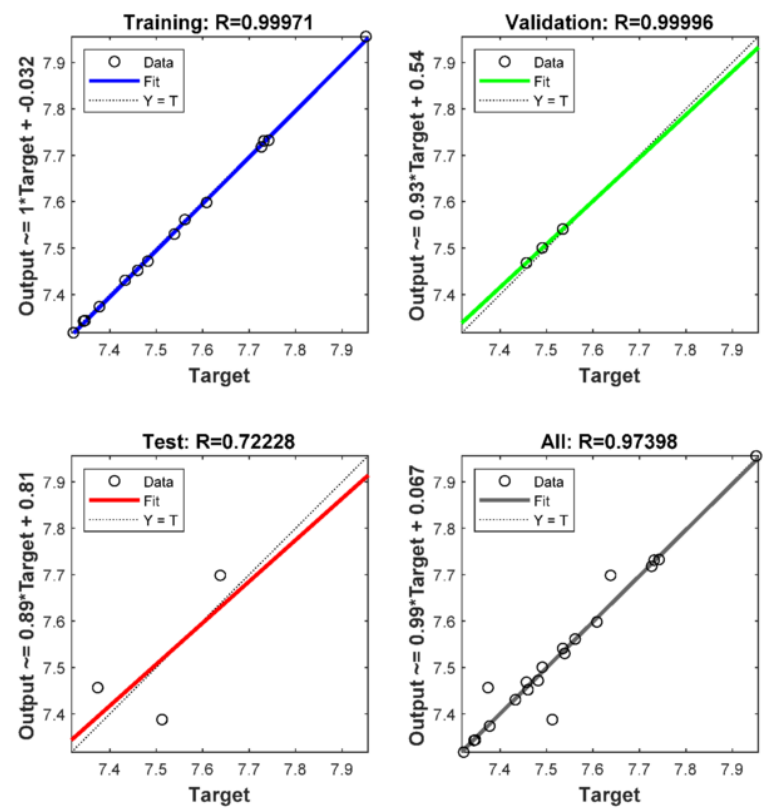

Figure 1. Neural network fitting results

\subsection{Results Analysis}

We evaluate the comprehensive level of 5 supplier samples based on the BP neural network model function obtained by training. The results are shown in table 2. 
Table2. Error Analysis

\begin{tabular}{cccc}
\hline Number & The actual value & The forecast value & Relative error \\
\hline 1 & 7.6761 & 7.7195 & $0.56 \%$ \\
2 & 7.4560 & 7.6958 & $3.22 \%$ \\
3 & 7.4577 & 7.6270 & $2.27 \%$ \\
4 & 7.6566 & 7.8169 & $2.09 \%$ \\
5 & 7.6084 & 7.7275 & $1.57 \%$ \\
\hline
\end{tabular}

The table 2 shows that the maximum training error between the actual value and the predicted value of each sample is $3.22 \%$, within the allowed error range, and the actual value curve has the same trend as the forecast value curve. In summary, the trained BP neural network model has a good evaluation function. This neural network integrates expert experience in the process of machine training and can be used for supplier selection. With the continuous improvement of prefabricated building information technology and the structured integration of data, the use of neural networks for supplier selection can simplify the process of supplier selection and improve the efficiency of the entire process.

\section{Conclusion}

The selection of PCs suppliers of prefabricated buildings is an important part of the widespread promotion and development of prefabricated buildings. Thus, it is particularly important to construct an evaluation selection method with strong adaptability, operability and dynamic change.

This paper fully considers the characteristics of prefabricated buildings and the elements of supplier selection, combined with the SCOR model to analyze the process of prefabricated building, and builds an evaluation index system for the selection of PCs of prefabricated building. We use the AHP to assign weights to each evaluation index, and provides a reliable basis for expert decision-making. Finally, we build a BP neural network model based on the MATLAB neural network toolbox, and verify the feasibility of the model through data simulation. The requirements for suppliers of prefabricated components for prefabricated buildings are gradually increasing with the development of prefabricated buildings. This not only requires suppliers to provide exact products on time, but also requires suppliers to provide some services including transportation and installation. The supplier selection method proposed in this paper can simplify the supplier selection process and improve the efficiency of supplier selection with information technology.

\section{Acknowledgement}

This paper is supported by the National Natural Science Foundation of China under Grant 61772062; China Federation of Logistics and Purchasing under Grant 2021CSLKT3-160. 


\section{References}

[1] Dickson G W. An Analysis Of Vendor Selection Systems And Decisions [J]. Journal of Purchasing, 1966, 2(15):28-41.

[2] Weber C A, Current J R, Benton W C. Vendor selection criteria and methods [J]. European Journal of Operational Research, 2007, 50(1):2-18.

[3] Zhang, Q.X., Yan J.J., Ye, W. GRAP-VIKOR-based supplier selection decision for assembly building PC components [J]. Journal of Civil Engineering and Management, 2020, 37 (01): 165-172.

[4] Shi, X.B., Ren, J., and Liu, C.C. Assembly building prefabricated components supplier evaluation index system construction [J]. Construction Economy, 2019, 40 (01): 92-97.

[5] Yang, S. 1., Huang P., Liu, W., and Liu, L. Intuitively fuzzy TODIM assembly building prefabricated components supplier selection [J]. Construction Economy, 2019, 40 (10): 40-45.

[6] Zhang, Z. M. Evaluation of supplier selection for prefabricated building components based on intuitionistic fuzzy VIKOR method [D]. Qingdao Technological University, 2018.

[7] Qin, X. F. Construction of supplier selection evaluation model based on BP neural network theory [J]. Business Economics Research,2015(27):24-25. 